\title{
Association of Serum Lipids with High Blood Pressure and Hypertension among Diabetic Patients. Mathematical Regression Models to Predict Blood Pressure from Lipids. An Experience from 12-year Follow Up of more than 9000 Patients' Cohort
}

\section{Kamran Mahmood Ahmed Aziz}

Consultant Diabetologist, Honorary Professor and Research Scientist (Endocrinology, Diabetes and Metabolism), Aseer Diabetes Center of Aseer Central Hospital, Ministry of Health, Saudi Arabia

"Corresponding author: Aziz KMA, Diabetology Clinic, Aseer Diabetes Center, Aseer Central Hospital, Ministry of Health, P.O.Box 34, Abha, Saudi Arabia, Tel: 00966-568361040; E-mail: drkamran9999@yahoo.com

Rec date: July 25, 2017; Acc date: September 18, 2017; Pub date: September 21, 2017

Copyright: (C) 2017 Aziz KMA. This is an open-access article distributed under the terms of the Creative Commons Attribution License, which permits unrestricted use, distribution, and reproduction in any medium, provided the original author and source are credited.

\begin{abstract}
Dyslipidemia and hypertension alone predispose to the risk of coronary artery disease, especially if the patient is diabetic. This risk is increased and multiplied when both dyslipidemia and hypertension coexists. There is a lack of studies and significant data for the correlation or association of blood pressure with serum lipids. The studies conducted in the past showed the conflicting results with poor associations. Furthermore, these studies were not conducted on diabetic subjects and lack regression models or mathematical linear equations. Hence, we conducted a prospective, observational cohort study on 9340 diabetic subjects for the duration of 12 year (2005-2017), with the aim to find significant associations, correlations between serum lipids (total cholesterol, triglycerides, LDL-C, HDL-C and Non-HDL-C) and blood pressure (systolic and diastolic). Our data has demonstrated that total cholesterol, triglycerides, and LDL-C were significantly correlated with systolic and diastolic BP, and raised among hypertensive patients as compared to non-hypertensive $(p<0.001$ for all lipids). The highest correlations were found between Non-HDL-C with systolic and diastolic blood pressures $(r=0.414$ and $r=0.415$, respectively with $p<0.001)$. However, HDL-C was inversely correlated with systolic and diastolic BP and was raised among non-hypertensive patients. Regression models and mathematical linear equations were developed to estimate increasing blood pressure by the given serum lipid levels. All regression models were significant $(p<0.0001)$. We concluded and developed regression models, for the first time in medical research that high lipid levels contribute to the development of increase systolic and diastolic blood pressures. With triglycerides, total-cholesterol, and HDL-C, Non-DHL-C levels should also be calculated in diabetology clinics and general practice. Screening should be done for diabetic patients to detect high blood pressure (or HTN) and elevated serum lipids, and early initiation of management to prevent diabetes complications.
\end{abstract}

Keywords: Lipids; Blood pressure; Coronary artery disease; Diabetes

\section{Introduction}

Currently hypertension is defined as the blood pressure (BP) values of $\geq 140 / 90 \mathrm{mmHg}$. Atherosclerotic cardiovascular disease (ASCVD) is one of the leading causes of morbidity and mortality among diabetic patients and also general population with high economic cost and burden [1-3]. Essential hypertension is the silent killer because it is usually asymptomatic and undetected. Uncontrolled hypertension can cause damage to all organs of body. Dyslipidaemia and hypertension are the commonest risk factors for coronary artery disease (CAD). Hypertension and hypercholesterolemia (or dyslipidemia) each predisposes to CAD and their combined effects are demonstrated to be multiplicative. There is also pronounced influence of blood pressure on the rate of atheroma formation in human subjects. Isolated systolic hypertension, commonly seen in elderly subjects, can be attributed to atherosclerosis induced stiffening of aorta and major arteries. Atherosclerosis is more extensive and severe in hypertensive patients than in normotensive; this was the conclusion after the autopsy studies conducted on human coronary arteries and aortas collected from various parts of the world [4-6].
Untreated hypertension has various adverse effects on the human body, including end organ damage. Both high blood pressure and elevated serum lipids are major risk factors for the development of ischemic heart disease (IHD) or CAD, and their progression is accelerated among diabetics. Furthermore, these metabolic abnormalities are also associated with macrovascular and microvascular complications of type 2 diabetes and risk factors for atherosclerosis in children and young adults [7-10].Current research literature has shown that diabetes mellitus is a cardio-vascular risk equivalent and has been further confirmed by Framingham study and other landmark studies [11,12]. Diabetic dyslipidemia is defined as elevated triglyceride, elevated low-density lipoprotein cholesterol (LDL-C) and low high density lipoprotein cholesterol (HDL-C) levels [13]. Furthermore, new guidelines have recommended targeting nonHDL cholesterol for reducing cardiovascular morbidity and mortality. Although in 1963 Albrink demonstrated that triglyceride was an important atherosclerotic risk in diabetes, however, recent trials have proved that by lowering triglyceride levels, primary end point of major coronary events was not reduced significantly. This evidence was further supported by Fenofibrate Intervention and Event Lowering in Diabetes (FIELD) study. Hence, it was demonstrated high density lipoprotein (HDL-C) is a strong inverse co-variate of triglyceride and 
HDL-C with Non-HDL-C must also be considered while managing dyslipidemia $[14,15]$.

In the past, some research trials were conducted and attempts were made to show a positive relation between serum total cholesterol and blood pressure [16-24]; however, their results were inconsistent and these trials concluded that these associations were insignificant. Some studies have shown positive correlations [25,26], but these studies were not conducted on diabetic subjects, and have not developed statistical regression models for serum lipids and blood pressure. Under this overview, the aim of the current study was to find associations and significant correlations between serum lipids (total cholesterol, LDL-C, HDL-C, Non-HDL-C and triglycerides) and to develop statistical regressions models and linear equations by which systolic and diastolic blood pressure elevations can be predicted or calculated by increasing serum lipids among diabetic patients.

\section{Methods}

This is a prospective, cross-sectional observational cohort study conducted at the diabetology clinic of Aseer Diabetes Center, Aseer Central Hospital. Total study duration was 12 years, from August 2005 until July 2017, with total number of patients 9340 , who, were routinely followed up in the diabetes clinic. We selected all type- 1 and type- 2 diabetic subjects who, were in regular follow up in the diabetes center. However, Children (age $<13$ years), pregnant diabetic women, and patients on end stage renal disease (ESRD) or on dialysis and with active hepatic disease were excluded from the study. Detail history and physical examination was done. Blood pressure was measured by standardized methodology. Blood pressure of $\geq 140 / 90$ was labelled as "hypertension". All blood samples were collected in fasting state of not less than 12 hours, early in the morning. Low-density lipoprotein cholesterol, LDL (mg/dl) was measured directly in plasma by Automated Low-Density Lipoprotein (ALDL) method for the Dimension $^{\circ}$ clinical chemistry system and analyzer (Siemens healthcare diagnostics Inc. Newark, DE 19714, U.S.A), in vitro diagnostic test intended for quantitative determination of LDL-C. HDL-C (mg/dl) was measured directly in plasma by Automated High Density Lipoprotein (AHDL) method by the Dimension ${ }^{\circ}$ clinical chemistry system and analyzer (Siemens healthcare diagnostics Inc. Newark, DE 19714, U.S.A), in vitro diagnostic test intended for quantitative determination of HDL-C. Similarly, total cholesterol (T. cholesterol) was measured directly by $\mathrm{CHOL}$ method (based on enzymatic procedures), a quantitative determination by the Dimension clinical chemistry system and analyzer. Non-HDL-C was calculated as total cholesterol - HDL-C. Serum triglyceride (mg/dl) was measured by an enzymatic procedure; the sample is incubated with lipoprotein lipase (LPL) enzyme reagent that converts triglycerides to free glycerol and fatty acids. These are further oxidized to dihyhroxyacetone phosphate and hydrogen peroxide $\left(\mathrm{H}_{2} \mathrm{O}_{2}\right)$ which is again converted to quinoneimine, absorbance of which is directly proportional to the total amount of glycerol. Absorbance is measured by bichromatic $(510,700 \mathrm{~nm})$ endpoint technique. Collectively, patients with $\mathrm{LDL} \geq 100 \mathrm{mg} / \mathrm{dl}$, triglycerides $\geq 150 \mathrm{mg} / \mathrm{dl}$ and $\mathrm{HDL} \leq 40 \mathrm{mg} / \mathrm{dl}$ were labeled as "dyslipidemia". All laboratory sample requests were entered in a computer software and results retrieved by Natcom Hospital Information System (NATCOM HIS; National Computer System Co. Ltd [27]. Patients' data were analyzed by IBM $^{\circ}$ SPSS $^{\oplus}$ statistics, version 20, for Microsoft Windows. All statistical tests were applied according to the available standard medical statistical methods.
Data were summarized as percentages with mean \pm SD and $95 \% \mathrm{CI}$ for the variables.

Normal distribution of variables was confirmed via SPSS by observing skewness and kurtosis values between -1 and +1 with no potential/influential outliers before further proceedings. Hence, this required no data transformations. For this purpose, normality tests were also performed with Q-Q plots, hence confirming their normal distribution. Independent $t$-test was performed to test the significant difference between groups of variables. Pearson's correlation analysis was used to test the correlation between variables.

Predictive regression models were used to develop relationship of serum lipids and blood pressures, and it was then estimated by mathematical linear equations to confirm that how serum lipids contribute to the development of high or increased blood pressure. This study was designed to have a statistical power of $90 \%$ to detect significant changes. All p-values were two-sided, and p-values less than 0.05 were considered statistically significant. This study was reviewed and approved by the research committee of Aseer Diabetes Center; consent was taken from the participating patients and all methodologies on subjects reported in current study were in accordance with Helsinki Declaration of 1975 (revised in 2008).

\section{Results}

Demographic data is presented in Table 1, while descriptive statistics is demonstrated in Table 2 . It was found that $42 \%$ of patients were hypertensive and $61 \%$ demonstrated dyslipidemia.

\begin{tabular}{|l|l|l|}
\hline \multirow{2}{*}{ Parameters } & \multicolumn{2}{|l|}{ Description with N (\%) ; Total=9340 } \\
\hline \multirow{2}{*}{ Type of Diabetes } & Male & Female \\
\cline { 2 - 3 } & $59 \%$ & $41 \%$ \\
\hline \multirow{2}{*}{ Hypertension status } & Type-1 & Hype-2 \\
\cline { 2 - 3 } & $16 \%$ & $84 \%$ \\
\cline { 2 - 3 } & $42 \%$ & Non-Hypertensive \\
\hline \multirow{2}{*}{ Dyslipidemia status } & Abnormal Lipids & $58 \%$ \\
\cline { 2 - 3 } & $61 \%$ & Normal Lipids \\
\hline
\end{tabular}

Table 1: Demographic data of diabetic patients.

Serum lipid values with or without hypertension status (with Mean \pm SD; $95 \%$ CI and p-values) is presented in Table 3. It was found that serum lipid values were higher among hypertensive patients ( $p$ value $<0.001$ for all serum lipids). However, HDL-C was lower in hypertensives ( $\mathrm{p}$-value $<0.001)$.

Tables 4 and 5, present the correlation between serum lipids and blood pressure (systolic and diastolic, respectively). It is evident from the tables that correlations and p-values were positively significant. However, HDL-C was found to be negatively significant with systolic and diastolic blood pressures. Regression models and linear equations for the serum lipids with systolic and diastolic blood pressures are presented in Tables 6 and 7, respectively. The linear mathematical equations are constructed in these tables by which systolic or diastolic $\mathrm{BP}$ can be calculated by the given lipid levels. All the models were found to be significant $(\mathrm{p}<0.0001)$. 
Citation: Aziz KMA (2017) Association of Serum Lipids with High Blood Pressure and Hypertension among Diabetic Patients. Mathematical Regression Models to Predict Blood Pressure from Lipids. An Experience from 12-year Follow Up of more than 9000 Patients' Cohort. Gen Med (Los Angeles) 5: 297. doi:10.4172/2327-5146.1000297

Page 3 of 7

\begin{tabular}{|l|l|}
\hline Variables & Mean \pm SD \\
\hline Age & $53 \pm 15$ \\
\hline Diabetes duration & $16 \pm 9.8$ \\
\hline Triglycerides $(\mathrm{mg} / \mathrm{dl})$ & $154 \pm 97.9$ \\
\hline Total cholesterol $(\mathrm{mg} / \mathrm{dl})$ & $190 \pm 48.8$ \\
\hline LDL-C $(\mathrm{mg} / \mathrm{dl})$ & $119 \pm 49.5$ \\
\hline HDL-C $(\mathrm{mg} / \mathrm{dl})$ & $42 \pm 18$ \\
\hline Non-HDL-C $(\mathrm{mg} / \mathrm{dl})$ & $151 \pm 48$ \\
\hline Systolic blood pressure $(\mathrm{mmHg})$ & $128.7 \pm 16.3$ \\
\hline Diastolic blood pressure $(\mathrm{mmHg})$ & $79.2 \pm 9$ \\
\hline
\end{tabular}

Table 2: Variables with descriptive statistics (mean $\pm \mathrm{SD})$.

\begin{tabular}{|c|c|c|c|}
\hline \multirow{2}{*}{$\begin{array}{l}\text { Serum lipids } \\
\text { (in } \mathrm{mg} / \mathrm{dl} \text { ) }\end{array}$} & \multicolumn{2}{|c|}{ Hypertension status with serum lipids } & \multirow{3}{*}{$\begin{array}{l}\text { P-value } \\
<0.001\end{array}$} \\
\hline & Yes & No & \\
\hline Total cholesterol & $194 \pm 50 ; 95 \% \mathrm{Cl} 190$ to 197 & $185 \pm 46 ; 95 \% \mathrm{Cl} 182$ to 189 & \\
\hline Triglycerides & $162 \pm 94 ; 95 \% \mathrm{Cl} 156$ to 169 & $152 \pm 89 ; 95 \% \mathrm{Cl} 146$ to 159 & $<0.001$ \\
\hline LDL-C & $123 \pm 55 ; 95 \% \mathrm{Cl} 119$ to 127 & $115 \pm 43 ; 95 \% \mathrm{Cl} 95$ to 105 & $<0.001$ \\
\hline HDL-C & $40 \pm 13 ; 95 \% \mathrm{Cl} 41$ to 39 & $43 \pm 23 ; 95 \% \mathrm{Cl} 42$ to 45 & $<0.001$ \\
\hline Non-HDL-C & $153 \pm 49 ; 95 \% \mathrm{Cl} 148$ to 155 & $147 \pm 45 ; 95 \% \mathrm{Cl} 142$ to 149 & $<0.001$ \\
\hline
\end{tabular}

Table 3: Serum lipids levels with hypertension state (Mean \pm SD; 95\% CI).

\begin{tabular}{|l|l|l|}
\hline $\begin{array}{l}\text { Variables tested for } \\
\text { correlations }\end{array}$ & $\begin{array}{l}\text { Pearson's correlation } \\
\text { coefficient }\end{array}$ & P-value \\
\hline Systolic BP and triglycerides & 0.391 & $<0.0001$ \\
\hline Systolic BP and total Cholesterol & 0.385 & $<0.001$ \\
\hline Systolic BP and LDL-C & 0.358 & $<0.01$ \\
\hline Systolic BP and HDL-C & -0.36 & $<0.01$ \\
\hline Systolic BP and Non-HDL-C & 0.414 & $<0.0001$ \\
\hline
\end{tabular}

Table 4: Correlation of lipids and systolic BP.

\begin{tabular}{|l|l|l|}
\hline $\begin{array}{l}\text { Variables tested for } \\
\text { correlations }\end{array}$ & $\begin{array}{l}\text { Pearson's Correlation } \\
\text { Coefficient }\end{array}$ & P-value \\
\hline Diastolic BP and triglycerides & 0.428 & $<0.0001$ \\
\hline Diastolic BP and T cholesterol & 0.383 & $<0.001$ \\
\hline Diastolic BP and LDL-C & 0.349 & $<0.01$ \\
\hline Diastolic BP and HDL-C & -0.371 & $<0.01$ \\
\hline Diastolic BP and Non-HDL-C & 0.415 & $<0.0001$ \\
\hline
\end{tabular}

Table 5: Correlation of lipids and diastolic BP.

\begin{tabular}{|l|l|l|l|l|}
\hline Variables & F-value & T-value & P-value & Regression/Linear equations y=a+bx \\
\hline Serum Triglyceride and systolic BP & 13.3 & 162.8 & $<0.0001$ & Sys BP = $126.3+(0.015 \times$ triglycerides $)$ \\
\hline Serum cholesterol and systolic BP & 11.65 & 74.95 & $<0.0001$ & Sys BP = $123.3+(0.029 \times$ total cholesterol) \\
\hline Serum LDL-C and systolic BP & 4.9 & 112.2 & $<0.0001$ & Sys BP $=126+(0.019 \times$ LDL $)$ \\
\hline Serum HDL-C and Systolic BP & 5.36 & 126 & $<0.0001$ & Sys BP $=130.6+(-0.052 \times \mathrm{HDL})$ \\
\hline Serum Non-HDL-C and systolic BP & 19.4 & 89.9 & $<0.0001$ & Sys BP $=105+(0.343 \times \mathrm{Non}-\mathrm{HDL}-\mathrm{C})$ \\
\hline
\end{tabular}

Table 6: Regression models for systolic blood pressure and serum lipids. 
Citation: Aziz KMA (2017) Association of Serum Lipids with High Blood Pressure and Hypertension among Diabetic Patients. Mathematical Regression Models to Predict Blood Pressure from Lipids. An Experience from 12-year Follow Up of more than 9000 Patients' Cohort. Gen Med (Los Angeles) 5: 297. doi:10.4172/2327-5146.1000297

Page 4 of 7

\begin{tabular}{|l|l|l|l|l|}
\hline Variables & F-Value & T-Value & P-Value & Regression/Linear Equations $\mathbf{y = a + b x}$ \\
\hline Serum Triglyceride and diastolic BP & 26.76 & 181.5 & $<0.0001$ & Dias BP $=77.27+(0.012 \times$ triglycerides $)$ \\
\hline Serum cholesterol and diastolic BP & 11.2 & 84.3 & $<0.0001$ & Dias BP $=76.2+(0.015 \times$ total cholesterol $)$ \\
\hline Serum LDL-C and diastolic BP & 3.5 & 126.6 & $<0.0001$ & Dias BP $=78+(0.009 \times$ LDL $)$ \\
\hline Serum HDL-C and diastolic BP & 7.4 & 141.3 & $<0.0001$ & Dias BP $=80.6+(-0.034 \times$ HDL $)$ \\
\hline Serum Non-HDL-C and diastolic BP & 19.6 & 101.1 & $<0.0001$ & Dias BP $=76+(0.21 \times$ Non-HDL-C $)$ \\
\hline
\end{tabular}

Table 7: Regression models for diastolic blood pressure and serum lipids.

\section{Discussion}

Management of dyslipidemia is an essential part of managing diabetes as a whole. In general clinical practice, physicians target LDL$\mathrm{C}$ as a primary target. However, recently to target non-HDL-C is also recommended. Non-HDL-C can be derived simply by abstracting HDL-C from total cholesterol which will give a better index of overall bad or harmful total cholesterol, a risk for CAD. According to recent evidence and recommendations from National Cholesterol Education Program (NCEP), target of LDL-C is to be $<100 \mathrm{mg} / \mathrm{dl}$ in patients with diabetes, followed by non-HDL-C cholesterol of $<130 \mathrm{mg} / \mathrm{dl}$ as a secondary target if triglyceride level remains elevated $(>200 \mathrm{mg} / \mathrm{dl})$. American Diabetes Association (ADA) has recommended similar management guidelines. This evidence indicates the importance of non-HDL-C as a potential marker of dyslipidemia [28-32]. It is essential to screen diabetic patients for dyslipidemia at initial and follow up visits as serum lipids contribute to the elevation of the blood pressure and poses CAD risk. Current study has demonstrated prevalence of diabetic dyslipidemia and hypertension to be $61 \%$ and $42 \%$ respectively, which is alarming. Furthermore, the data has demonstrated that hypertension state was associated with elevated serum lipids $(\mathrm{p}<0.001)$.

Although there are studies which have shown that elevated serum lipids are associated with high blood pressure or hypertension [16-24,33], however, they demonstrated conflicting results and their exact correlations with regression models were not developed in the past to predict BP elevation contributed by elevated serum lipids. No study has found correlation between non-HDL-C and blood pressure or HTN. Furthermore, these previous studies were not conducted in diabetic patients. This was achieved for the first time in the medical research history in our study. Between lipids and blood pressure, the highest correlations were found between non-HDL-C with systolic and diastolic blood pressures $(r=0.414$ and $r=0.415$, respectively, with $\mathrm{p}<0.001$ for both); after non-HDL, the correlations for triglycerides were significant with systolic and diastolic blood pressures $(r=0.391$ and $\mathrm{r}=0.428$, respectively with $\mathrm{p}<0.0001$ for both). HDL-C, a good cholesterol, was inversely related with systolic and diastolic blood pressures. Non-HDL-C (i.e., non-HDL-C=total cholesterol-HDL-C), gives the value for overall harmful cholesterol. Our data has demonstrated that correlations for non-HDL-C with blood pressures were the most significant, and this cholesterol or lipid is contributing most for the elevated BP or HTN. Although in general practice it is ignored, however, non-HDL-C must be considered in tertiary care diabetes centers to reduce cardio-metabolic risk among diabetics. The linear equations $(\mathrm{y}=\mathrm{a}+\mathrm{bx})$ can be used to predict blood pressures by given lipid values. For example, if given triglyceride value is $200 \mathrm{mg} / \mathrm{dl}$, the systolic and diastolic BP will be $129 \mathrm{mmHg}$ and $80 \mathrm{mmHg}$, respectively. However, if serum triglyceride value is 300 , for example, then according to the given linear equation, it can raise systolic BP up to $131 \mathrm{mmHg}$. Similarly, LDL-C levels of $180 \mathrm{mg} / \mathrm{dl}$ can lead to BP elevations up to approximately $129.5 \mathrm{~mm} \mathrm{Hg}$. Hence, by this technique physicians can know that chronic exposures of high serum lipids can lead to significant elevations in the near future. Additionally, and according to our statistical analysis, HDL-C levels should be raised as they are associated with reduced systolic and diastolic BP. Dylipidemia and high non-HDL-C cholesterol is also associated with hypothyroidism among diabetic patients, and requires screening with regular follow up. Additionally, it has been demonstrated in research trials that dyslipidemia is associated with the development of nephropathy and early detection of dyslipidemia with nephropathy is recommended in primary care clinics [34-36].

Hypertension or elevated blood pressure is associated with CAD, cerebrovascular disease (CVA) and other diabetes related complications as well. Diabetic patients are at risk of cardiovascular and atherosclerotic disease development and progression. Efforts should be made to reduce elevated blood pressure among diabetics with available medications, as tight blood pressure control have shown reductions in morbidity and mortality and diabetes related complications [37-53]. Additionally, diabetic patients should be screened for dyslipidemia as well, as this pathological state leads to CAD or IHD with high morbidity and mortality rates. Dylipidemia and high triglycerides are associated with insulin resistance. Free fatty acid-induced insulin resistance is associated with activation of protein kinase $\mathrm{C}$-theta $(\mathrm{C}-\theta)$ and alterations in the insulin signaling cascade. Aggressive treatment should be initiated if dyslipidemia is detected with statins [54-62]. Furthermore, during management of diabetes in diabetology clinics, diabetologist should consider options for the management of type- 1 and type- 2 diabetic patients. For type-1, basal bolus insulin is the best strategy. For type-2 diabetics, oral agents (sulfonylurea or oral hypoglycemic agents, Metformin, DPP-4 inhibitors, SGLT-2 inhibitors, thiazolidinediones) can be used alone or in combination with insulin; these treatments can be shifted to insulin with metformin if they remain uncontrolled on oral agents. Metformin should be prescribed to type-2 diabetic patients (if not contraindicated) because metformin has cardiovascular protective effects, reduces insulin resistance, increases insulin sensitivity, and decreases the serum lipids while elevates HDL-C as has been demonstrated by research studies [63-70]. It is recommended following best available guidelines for the management of diabetes and its complications $[71,72]$.

Our research, for the first time in medical history has demonstrated significant correlations, associations and regression models/linear mathematical equations between serum lipids (including non-HDL-C) 
and blood pressure (or HTN). Most significant elevations of BP were attributed due to raised non-HDL-C and then the triglycerides. Further research at multi-center level and randomized controlled trials are required to confirm the findings of the current study.

\section{Conclusion and Recommendations}

Diabetes mellitus is cardiovascular risk equivalent and cardiovascular atherosclerotic disease is accelerated in diabetics. These conditions are resulting due to the coexistence dyslipidemia and hypertension. While these two pathologies predispose to the cardiovascular risk, these may also cause development or progression of nephropathy. While managing diabetes, it is recommended to screen these patients for hypertension, dyslipidemia, and nephropathy and to initiate management at early stages to prevent diabetes related complications.

\section{Conflict of Interest and Funding}

Author declares no conflict of interest in this work. This study was not funded by any organization. For the current research project, corresponding author himself designed the study, reviewed the literature, collected and analyzed the data with paper and medical writing.

\section{References}

1. American Diabetes Association (2016) Cardiovascular disease and risk management. Diabetes Care 40: S75-S87.

2. Aziz KMA (2014) Association of microalbuminuria with ischemic heart disease, dyslipidemia and obesity among diabetic patients: experience from 5 year follow up study of 1415 patients. Bioenergetics 3: 118 .

3. Mathers CD, Loncar D (2006) Projections of global mortality and burden of disease from 2002 to 2030. PLoS Med 3: e442.

4. Report of Inter-Society Commission for Heart Disease Resources (1970) Primary prevention of the atherosclerotic diseases. Circulation 42: A55A95.

5. Brand RJ (1977) An examination of the association between a-b behavior and coronary heart disease incidence: Proceedings of the forum on coronary prone behavior, St. Petersburg, Florida.

6. Criqui MH, Barrett-Connor E, Holdbrook MJ, Austin M, Turner JD (1980) Clustering of cardiovascular disease risk factors. Prev Med 9: 525-533.

7. MacMahon SW, Macdonald GJ, Blacket RB (1985) Plasma lipoprotein levels in treated and untreated hypertensive men and women: The National Heart Foundation of Australia Risk Factor Prevalence Study. Arteriosclerosis 5: 391-396.

8. Julius S, Jamerson K, Mejia A, Krause L, Schork N, et al. (1990) The association of borderline hypertension with target organ changes and higher coronary risk: Tecumseh Blood Pressure study. J Am Med Assoc 264: 354-358.

9. Adler AI, Stratton IM, Neil HA, Yudkin JS, Matthews DR, et al. (2000) Association of systolic blood pressure with macrovascular and microvascular complications of type 2 diabetes (UKPDS 36): Prospective observational study. Br Med J 321: 412-419.

10. Berenson G, Srinivasan S, Bao W, Newman W, Tracy R, et al. (1998) The Bogalusa heart study: Association between multiple cardiovascular risk factors and atherosclerosis in children and young adults. N Engl J Med 338: 1650-1656.

11. Kannel WB, McGee DL (1979) Diabetes and cardiovascular disease: The Framingham study. J Am Med Assoc 241: 2035-2038.

12. Kannel WB, McGee DL (1979) Diabetes and glucose tolerance as risk factors for cardiovascular disease: The Framingham study. Diabetes Care 2: $120-126$.
13. Goldberg IJ (2001) Diabetic dyslipidemia: Causes and consequences. J Clin Endocrinol Metab 86: 965-971.

14. Albrink MJ, Lavietes PH, Man EB (1963) Vascular disease and serum lipids in diabetes mellitus. Observations over thirty years (1931-1961). Ann Intern Med 58: 305-323.

15. Keech A, Simes RJ, Barter P, Best J, Scott R, et al. (2005) Effects of longterm fenofibrate therapy on cardiovascular events in 9795 people with type 2 diabetes mellitus (the FIELD study): Randomized controlled trial. Lancet 366: 1849-1861.

16. Keys A, Aravanis C, Blackburn H, Buzina R, Djordjevic BS, et al. (1980) Seven Countries: A multivariate analysis of death and coronary heart disease. Harvard University Press, Cambridge, Mass/London.

17. Salonen JT, Puska P, Kottke TE, Heinonen OP (1981) Coronary risk factor clustering patterns in eastern Finland. Int J Epidemiol 10: 203-210.

18. Hjermann I, Helgeland A, Holme I, Lund-Larsen PG, Leren P (1978) The association between blood pressure and serum cholesterol in healthy men: The Oslo study. J Epidemiol Community Health 32: 117-123.

19. Castelli WP, Anderson K (1986) A population at risk: Prevalence of high cholesterol levels in hypertensive patients in the Framingham study. Am J Med 80: 23-32.

20. Stamler J, Rhomberg P, Schoenberger JA, Shekelle RB, Dyer A, et al. (1975) Multivariate analysis of the relationship of seven variables to blood pressure: Findings of the Chicago Heart Association Detection Project in Industry, 1967-1972. J Chronic Dis 28: 527-548.

21. Criqui MH, Cowan LD, Heiss G, Haskell WL, Laskarzewski PM, et al. (1986) Frequency and clustering of nonlipid coronary risk factors in dyslipoproteinemia: The Lipid Research Clinics program prevalence study. Circulation 73: 140-150.

22. Laurenzi M, Mancini M, Menotti A, Stamler J, Stamler R, et al. (1990) Multiple risk factors in hypertension: Results from the Gubbio study. J Hypertens 8: S7-S12.

23. Ostrander LD (1976) Coronary risk factors in a community: Findings in Tecumseh, Michigan. Circulation 53: 152-156.

24. Natvig H, Borchgrevink CF, Dedichen J, Owren PA, Schiotz EH, et al. (1968) A controlled trial of the effect of linolenic acid on incidence of coronary heart disease: The Norwegian vegetable oil experiment of 1965-66. Scand J Clin Lab Invest Suppl 105: 1-20.

25. Bønaa KH,Thelle DS (1991) Association between blood pressure and serum lipids in a population. The Tromsø study. Circulation 83: 1305-1314.

26. Saely CH, Risch L, Frey F, Lupi GA, Leuppi JD, et al. (2009) Body mass index, blood pressure, and serum cholesterol in young Swiss men: An analysis on 56784 army conscripts. Swiss Med Wkly 139: 518-524.

27. http://natcom.com.sa/healthcare and http://natcom.com.sa/ clients

28. Expert Panel on Detection, Evaluation, and Treatment of High Blood Cholesterol in Adults (2001) Executive summary of the third report of the National Cholesterol Education Program (NCEP) expert panel on detection, evaluation, and treatment of high blood cholesterol in adults (Adult Treatment Panel III). J Am Med Assoc 285: 2486-2497.

29. Brunzell JD, Davidson M, Furberg CD, Goldberg RB, Howard BV, et al. (2008) Lipoprotein management in patients with cardio-metabolic risk: Consensus statement from the American Diabetes Association and the American College of Cardiology Foundation. Diabetes Care 31: 811-822.

30. Genest J (2002) Genetics and prevention: A new look at high-density lipoprotein cholesterol. Cardiol Rev 10: 61-71.

31. Robins SJ, Collins D, Wittes JT, Papademetriou V, Deedwania P, et al. (2001) Relation of gemfibrozil treatment and lipid levels with major coronary events. VA-HIT: A randomized controlled trial. J Am Med Assoc 285: 1585-1591.

32. Aziz KMA (2013) Association between Non-HDL and HDL Cholesterol with microalbuminuria in patients with Diabetes. J Diabetol 4: 6.

33. Choudhury KN, Mainuddin AKN, Wahiduzzaman M, Shariful ISM (2014) Serum lipid profile and its association with hypertension in Bangladesh. Vasc Health Risk Manag 10: 327-332. 
34. Aziz KMA (2016) Association of hypothyroidism with high non-HDL cholesterol and ankle brachial pressure index in patients with diabetes: 10-Year Results from a 5780 Patient Cohort. A Need for Intervention. Annals Thyroid Res 2: 53-57.

35. Aziz KMA (2012) Targeting LDL dyslipidemia for controlling progression of nephropathy in diabetic population: A cross sectional analytical study. J Dow Univ Health Sci 6: 7-11.

36. Aziz KMA (2016) Association between hypothyroidism, body mass index, systolic blood pressure and proteinuria in diabetic patients: does treated hypothyroid with thyroxine replacement therapy prevent nephropathy/ chronic renal disease?. Curr Diabetes Rev 12: 297-306.

37. American Diabetes Association. (2011) Standards of medical care in diabetes--2011. Diabetes Care 34: S11-S61.

38. Ravid M, Lang R, Rachmani R, Lishner M (1996) Long-term renoprotective effect of angiotensin-converting enzyme inhibition in noninsulin-dependent diabetes mellitus. A 7-year follow-up study. Arch Intern Med 156: 286-289.

39. UKPDS (1998) Tight blood pressure control and risk of macrovascular and microvascular complications in type 2 diabetes: UKPDS 38. UK Prospective Diabetes Study Group. BMJ 317: 703-713.

40. Chobanian AV, Bakris GL, Black HR, Cushman WC, Green LA, et al (2003) The seventh report of the joint national committee on prevention, detection, evaluation, and treatment of high blood pressure: the JNC 7 report. J Am Med Assoc 289: 2560-2572.

41. Estacio RO, Jeffers BW, Gifford N, Schrier RW (2000) Effect of blood pressure control on diabetic microvascular complications in patients with hypertension and type 2 diabetes. Diabetes Care 23: B54-B64.

42. Schrier RW, Estacio RO, Esler A, Mehler P (2002) Effects of aggressive blood pressure control in normotensive type 2 diabetic patients on albuminuria, retinopathy and strokes. Kidney Int 61: 1086-1097.

43. Mancia G (2010) Effects of intensive blood pressure control in the management of patients with type 2 diabetes mellitus in the Action to Control Cardiovascular Risk in Diabetes (ACCORD) trial. Circulation 122: 847-849.

44. Ninomiya T, Zoungas S, Neal B, Woodward M, Patel A, et al. (2010) Efficacy and safety of routine blood pressure lowering in older patients with diabetes: Results from the ADVANCE trial. J Hypertens 28: 11411149 .

45. Cushman WC, Evans GW, Byington RP, Goff DC, Grimm RH Jr, et al. (2010) Effects of intensive blood-pressure control in type 2 diabetes mellitus. N Engl J Med 362: 1575-1585.

46. Varughese GI, Lip GY (2005) Antihypertensive therapy in diabetes mellitus: Insights from ALLHAT and the Blood Pressure-Lowering Treatment Trialists' Collaboration meta-analysis. J Hum Hypertens 19 851-853.

47. ALLHAT Officers and Coordinators for the ALLHAT Collaborative Research Group (2002) Major outcomes in high-risk hypertensive patients randomized to angiotensin-converting enzyme inhibitor or calcium channel blocker vs diuretic: The antihypertensive and LipidLowering Treatment to Prevent Heart Attack Trial (ALLHAT). J Am Med Assoc 288: 2981-2997.

48. Berl T, Hunsicker LG, Lewis JB, Pfeffer MA, Porush JG, et al. (2005) Impact of achieved blood pressure on cardiovascular outcomes in the Irbesartan Diabetic Nephropathy Trial. J Am Soc Nephrol 16: 2170-2179.

49. Dahlöf B, Sever PS, Poulter NR, Wedel H, Beevers DG, et al. (2005) Prevention of cardiovascular events with an antihypertensive regimen of amlodipine adding perindopril as required versus atenolol adding bendroflumethiazide as required, in the Anglo-Scandinavian Cardiac Outcomes Trial-Blood Pressure Lowering Arm (ASCOT-BPLA): A multicentre randomised controlled trial. Lancet 366: 895-906.

50. Agardh CD, Garcia-Puig J, Charbonnel B, Angelkort B, Barnett AH. (1996) Greater reduction of urinary albumin excretion in hypertensive type II diabetic patients with incipient nephropathy by lisinopril than by nifedipine. J Hum Hypertens 10: 185-192.
51. Chan JC, Ko GT, Leung DH, Cheung RC, Cheung MY, et al. (2000) Longterm effects of angiotensin-converting enzyme inhibition and metabolic control in hypertensive type 2 diabetic patients. Kidney Int 57: 590-600.

52. Laffel LM, McGill JB, Gans DJ (1995) The beneficial effect of angiotensinconverting enzyme inhibition with captopril on diabetic nephropathy in normotensive IDDM patients with microalbuminuria. North American Microalbuminuria Study Group. Am J Med 99: 497-504

53. Sever PS, Dahlof B, Poulter NR, Wedel H, Beevers DG, et al. (2001) Rationale, design, methods and baseline demography of participants of the Anglo-Scandinavian Cardiac Outcomes Trial. J Hypertens 19: 1139-1147.

54. Liu Y, Zhang B, Chen JY, Chen PY (2013) The relationship between fasting triglyceride level and prevalence and severity of angiographic coronary artery disease in 16,650 patients from the TRUST study in the statins era. Eur Heart J 34: P1550.

55. Karthikeyan G, Teo KK, Islam S, McQueen MJ, Pais P, et al. (2009) Lipid profile, plasma apolipoproteins, and risk of a first myocardial infarction among Asians: An analysis from the INTERHEART Study. J Am Coll Cardiol 53: 244-253.

56. Sharrett AR, Ballantyne CM, Coady SA, Heiss G, Sorlie PD, et al. (2001) Coronary heart disease prediction from lipoprotein cholesterol levels, triglycerides, lipoprotein(a), apolipoproteins A-I and B, and HDL density subfractions: The Atherosclerosis Risk in Communities (ARIC) Study. Circulation 104: 1108-1113.

57. Widen E, Ekstrand A, Saloranta C, Franssila-Kallunki A, Eriksson J, et al. (1992) Insulin resistance in type 2 (non-insulin-dependent) diabetic patients with hypertriglyceridaemia. Diabetologia 35: 1140-1145.

58. Rosenson RS, Lowe GD (1998) Effects of lipids and lipoproteins on thrombosis and rheology. Atherosclerosis 140: 271-280.

59. Protogerou AD, Safar ME, Iaria P, Safar H, Le Dudal K, et al. (2007) Diastolic blood pressure and mortality in the elderly with cardiovascular disease. Hypertension 50: 172-180.

60. Bays HE (2012) Adiposopathy, diabetes mellitus, and primary prevention of atherosclerotic coronary heart disease: Treating "sick fat" through improving fat function with anti-diabetes therapies. Am J Cardiol 110: 4 B -12B.

61. Griffin ME, Marcucci MJ, Cline GW, Bell K, Barucci N, et al. (1999) Free fatty acid-induced insulin resistance is associated with activation of protein kinase $\mathrm{C}$ theta and alterations in the insulin signaling cascade. Diabetes 48: 1270-1274.

62. Ekelund LG, MacMahon RP, Whaley FS, Corder EH, Rubenstein CL (1988) Does lowering of cholesterol with cholestyramine decrease the incidence of hypertension in hypercholesterolemic men? The LRC coronary primary prevention trial (abstract). CVD Epidemiol Newslett 43: 13 .

63. Giannarelli R, Aragona M, Coppelli A, Del Prato S (2003) Reducing insulin resistance with metformin: The evidence today. Diabetes Metab 29: 6S28-6S35.

64. Johnson A, Webster J, Sum C, Heseltine L, Argyraki M, et al. (1993) The impact of metformin therapy on hepatic glucose production and skeletal muscle glycogen synthase activity in overweight type II diabetic patients. Metabolism 42: 1217-1222.

65. Fontbonne A, Charles M, Juhan-Vague I, Bard J, Andre P, et al. (1996) The effect of metformin on the metabolic abnormalities associated with upper-body fat distribution. BIGPRO Study Group. Diabetes Care 19: 920-926.

66. Stratton IM, Holman RR (2003) The cardioprotective effects of metformin may not be dose-dependent. Diabet Med 20: A55.

67. Legtenberg R, Houston R, Oeseburg B, Smits P (2002) Metformin improves cardiac functional recovery after ischemia in rats. Horm Metab Res 34: 182-185.

68. Calvert J, Gundewar S, Jha S, Greer J, Bestermann W, et al. (2008) Acute metformin therapy confers cardioprotection against myocardial infarction via AMPK-eNOS-mediated signaling. Diabetes 57: 696-705. 
Citation: Aziz KMA (2017) Association of Serum Lipids with High Blood Pressure and Hypertension among Diabetic Patients. Mathematical Regression Models to Predict Blood Pressure from Lipids. An Experience from 12-year Follow Up of more than 9000 Patients' Cohort. Gen Med (Los Angeles) 5: 297. doi:10.4172/2327-5146.1000297

Page 7 of 7

69. Louro T, Matafome P, Nunes E, da Cunha F, Seiça R (2011) Insulin and metformin may prevent renal injury in young type 2 diabetic GotoKakizaki rats. Eur J Pharmacol 653: 89-94.

70. Aziz KMA (2014) Unique glycemic and cardio-renal protective effects of metformin therapy among type-2 diabetic patients: A lesson from a five year cross-sectional observational study of 1590 patients. Research 1: 874.

71. Aziz KMA (2012) Management of type-1 and type-2 diabetes by insulin injections in diabetology clinics - A scientific research review. Recent Pat Endocr Metab Immune Drug Discov 6: 148-170.
72. Nathan DM, Buse JB, Davidson MB, Ferrannini E, Holman RR, et al (2009) Medical management of hyperglycemia in type 2 diabetes: A consensus algorithm for the initiation and adjustment of therapy: A consensus statement of the American Diabetes Association and the European Association for the Study of Diabetes. Diabetes Care 32: 193-203. 